\title{
PENGEMBANGAN MOBILE ADVERTISING SEBAGAI SARANA PROMOSI TOKO ROTI DAN KUE MENGGUNAKAN LOCATION BASED SERVICE
}

\author{
Ika Arfiani,S.T., M.Cs. \\ Program Studi Teknik Informatika Universitas Ahmad Dahlan \\ Jalan Prof. Dr. Soepomo, SH,. Janturan, Warungboto, Umbulharjo Yogyakarta 55164 \\ e-mail : ika.arfiani@tif.uad.ac.id
}

\begin{abstract}
ABSTRAK
Pertumbuhan pengguna layanan mobile data dan mobile internet di Indonesia meningkat pesat dibandingkan voice dan sms. Sehingga kehidupan manusia bagai tak terpisah antara jarak, tempat, dan waktu. Dengan mudahnya manusia dapat melakukan komunikasi dan mengakses informasi tak peduli dimanapun dia tempatnya. Apalagi dengan beragamnya alat komunikasi yang kini beredar ditengah masyarakat, salah satunya adalah smartphone android.

Permasalahan yang umum dihadapi adalah bagaimana membangun suatu aplikasi pada platform Android untuk pencarian lokasi toko roti dan kue beserta alamatnya. Hal tersebut telah terjawab dengan adanya sistem operasi android yang open source, Dengan adanya aplikasi ini maka pengguna yang mempunyai tingkat kesibukan atau mobilitas yang tinggi tidak perlu lagi mencari lokasi toko roti dengan mencari ataupun bertanya dimana lokasi toko roti yang terdekat, karena Aplikasi ini telah menyediakan fitur pencarian secara lengkap, sehingga pengguna dapat mencari lokasi toko roti yang terdekat kapanpun dan dimanapun hanya dengan ponsel Android yang dimilikinya. Kelebihan aplikasi ini dapat digunakan untuk membantu mencari lokasi toko roti dan kue berdasarkan jenis tokonya serta lokasi yang terdekat dari posisi kita berada. Aplikasi ini akan menampilkan secara detail informasi dari toko yang ada berupa nama, alamat, nomor telepon, gambar / foto dan tampilan peta yang bersumber dari Google Maps.

Hasil pengujian sistem menunjukkan bahwa aplikasi dapat memberikan informasi lokasi toko kepada pengguna, melakukan panggilan telepon ke toko yang dituju, melakukan share promosi, serta menampilkan map sekaligus rute terpendek menuju lokasi merchant yang ingin dituju. Rute terpendek yang didapat telah mampu menemukan lokasi tujuan dengan jarak yang relative pendek dan tergambar dalam google map.
\end{abstract}

Kata Kunci : Android, Mobile Application, Rute Terpendek, Location Based Service,

\section{PENDahuluan}

Location Base Service(LBS) adalah layanan yang menyediakan informasi berdasarkan tempat, mengacu pada GIS atau electronic map yang ditunjukkan oleh garis lintang dan bujur sehingga mendapatkan titik lokasi yang akurat [1]. Di tengah begitu pesatnya perkembangan aplikasi pada smartphone, masih terdapat pangsa pasar yang sangat luas untuk aplikasi LBS yang belum dikerjakan dengan baik [2]. Salah satu aplikasi yang masih bisa dikembangkan adalah aplikasi E-Advertising, contohnya penggunaan teknik layanan mobile advertising ini.

Selain untuk meningkatkan omset/pendapatan, layanan iklan juga dapat lebih mengenalkan produk kepada para konsumen. Seperti contohnya pada kawasan industri roti atau kue yang ada di Yogyakarta, mereka senantiasa berkembang dan berusaha untuk bisa mengimbangi kemajuan peradaban teknologi dengan mengikuti trend periklanan yang sedang marak saat ini. Mereka melakukan berbagai cara promosi yang menarik seperti menginformasikan secara online, memberikan kupon diskon, membuat brosur atau pamflet, dan yang marak dilakukan saat ini adalah melakukan promosi melalui aplikasi smartphone. Smartphone pada saat ini umumnya telah memiliki fasilitas Global Positioning System (GPS) yang memungkinkan pengguna untuk mengetahui lokasi dimana dirinya berada sekarang. 
Adapun untuk proses perhitungan jarak terdekat antara lokasi pengguna dengan lokasi toko/merchant pada aplikasi ini diterapkan metode Haversine, karena seperti dalam (Adiwilaga, 2014) Haversine Formula biasa digunakan untuk menghitung jarak Orthodromic. Jarak Orthodromic adalah jarak terpendek antara dua titik di permukaan bumi menggunakan garis lintang (longitude) dan garis bujur (lattitude) sebagai variabel inputan. Sedangkan untuk masalah pencarian rute terpendek menuju lokasi tujuan diawali dengan mengetahui posisi asal dan posisi tujuan (merchant) yang akan dikunjungi. Posisi-posisi inilah yang akan digunakan untuk proses pembangunan rute perjalanan dalam pencarian rute terpendek. Untuk selanjutnya hasil pencarian rute ini akan ditampilkan melalui Google Map.

\section{LANDASAN TEORI}

\subsection{Location Based Service}

Location-Based Services(LBS) adalah suatu cara menyampaikan layanan data dan informasidimana isi dari layanan tersebut disesuaikan pada lokasi terkini daripengguna mobile phone. Ini adalah sebuah teknologi baru yangberkembang cepat dengan menggabungkan Geografi Information System (GIS), teknologi nirkabel, sistem penentuan lokasi serta interaksi manusiadan komputer pada perangkat mobile.[4]

Beberapa contoh aplikasi yang menerapkan layanan berbasis lokasi diantaranya untuk pemetaan aplikasi dan alat menemukan rute terpendek dan restoran terdekat [5]. Lokasi dapat dinyatakan dalam bentuk data spasial atau deskripsi teks. Posisi spasial dapat dinyatakan menggunakan latitude, longitude dan altitude. Latitude dinyatakan dalam nilai 0-90 derajat utara atau selatan dari garis khatulistiwa. Longitude dinyatakan dengan nilai 0 - 180 derajat timur atau barat dari prime meridian. Prime meridian adalah sebuah garis virtual yang melewati sebuah kota bernama Greenwich di Inggris. Altitude menyatakan tinggi permukaan dari permukaan laut. Deskripsi teks biasanya digunakan untuk menyatakan jalan, kota, kode pos dan lain-lain [6].

\subsection{E-advertising (Mobile Advertising)}

Definisi iklan adalah segala bentuk promosi dan presentasi nonpersonal atas sebuah ide, barang, atau layanan yang dibayarkan oleh sponsor yang teridentifikasi[7]. Iklan pada dasarnya merupakan sebuah bentuk komunikasi massa berbayar yang bersifat non personal, bertujuan untuk memberi informasi tentang sebuah organisasi, produk, layanan atau ide dari sebuah sponsor tertentu. Iklan juga merupakan media informasi yang dibuat sedemikian rupa agar menarik minat khalayak, orisinil, serta memiliki karakteristik tertentu dan persuasif sehingga para konsumen atau khalayak secara sukarela terdorong untuk melakukan sesuatu tindakan sesuai dengan yang diinginkan pengiklan[8].

Salah satu cabang dari LBS dalam bidang periklanan yakni Location Based Advertising(LBA). LBA mencakup aplikasi layanan berbasis lokasi untuk memungkinkan penyedia konten menawarkan informasi kepada pelanggan pada waktu dan tempat yang tepat. Layanan dalam LBA dikategorikan dalam dua layanan yaitu LBA push dan LBA pull. Dalam LBA push layanan diambil ketika suatu fungsi kondisi telah terpenuhi, semisal mendapatkan notifikasi secara pasif. Lain halnya dengan layanan LBA pull, pengguna diminta untuk memasukkan sebuah input yang akan memanggil suatu fungsi agar kondisi terpenuhi[9].

\subsection{Google Maps API}

Google Map adalah layanan aplikasi dan teknologi peta berbasis web yang disediakan oleh Google secara gratis. Sebuah peta dapat disisipkan pada website lain melalui google map API yakni aplikasi antar muka yang dapat di akses melalui JavaScript. API tersebut menyediakan banyak fasilitas dan utilitas untuk memanipulasi peta dan menambahkan konten pada peta melalui berbagai layanan. Terdapat dua cara utuk mengakses data dari Google Maps, tergantung 
pada data yang akan diambil dan di parsing dalam google maps, yaitu dengan mendaftar API key dan tidak mendaftar API key.

\subsection{Google Geocoding API}

Geocoding adalah proses mengubah alamat seperti ("1600 Amphitheatre Parkway, Mountain View, CA") menjadi koordinat geografis (lintang 37,423021 dan bujur -122,083739), yang dapat digunakan untuk menempatkan penanda pada posisi peta. Google Geocoding API menyediakan cara langsung untuk mengakses geocoder melalui permintaan HTTP. Selain itu, layanan ini memungkinkan pengguna untuk melakukan operasi sebaliknya yaitu merubah koordinat menjadi alamat, proses ini disebut reverse geocoding.

\subsection{Android}

Arsitektur android seperti Gambar 1 dibagi menjadi lima bagian dalam empat lapisan[10].

\begin{tabular}{|c|c|c|c|c|}
\hline \multicolumn{5}{|c|}{ Applications and Widgets } \\
\hline Home & Contacts & Browser & Widgets & Your App Here \\
\hline \multicolumn{5}{|c|}{ Application Framework } \\
\hline $\begin{array}{l}\text { Activity } \\
\text { Manager }\end{array}$ & $\begin{array}{l}\text { Window } \\
\text { Manager }\end{array}$ & $\begin{array}{l}\text { Content } \\
\text { Providers }\end{array}$ & View System & $\begin{array}{l}\text { Notification } \\
\text { Manager }\end{array}$ \\
\hline $\begin{array}{l}\text { Package } \\
\text { Manager }\end{array}$ & $\begin{array}{l}\text { Telephony } \\
\text { Manager }\end{array}$ & Resource & $\begin{array}{l}\text { Location } \\
\text { Manager }\end{array}$ & $\begin{array}{l}\text { Sensor } \\
\text { Manager }\end{array}$ \\
\hline Libraries & & & \multicolumn{2}{|c|}{ Android Runtime } \\
\hline $\begin{array}{c}\text { Surface } \\
\text { Manager }\end{array}$ & $\begin{array}{c}\text { Media } \\
\text { Framework }\end{array}$ & SQLite & \multicolumn{2}{|c|}{ Core Libraries } \\
\hline OpenGL|ES & FreeType & WebKit & \multicolumn{2}{|c|}{$\begin{array}{l}\text { Dalvik Virtual } \\
\text { Machine }\end{array}$} \\
\hline SGL & SSL & libc & & \\
\hline \multicolumn{5}{|l|}{ Linux Kernel } \\
\hline Display Driver & $\begin{array}{l}\text { Bluetooth } \\
\text { Driver }\end{array}$ & Camera Driver & $\begin{array}{c}\text { Flash Memory } \\
\text { Driver }\end{array}$ & $\begin{array}{l}\text { Binder (IPC) } \\
\text { Driver }\end{array}$ \\
\hline Keypad Driver & USB Driver & WiFi Driver & Audio Drivers & $\begin{array}{c}\text { Power } \\
\text { Management }\end{array}$ \\
\hline
\end{tabular}

Gambar 1. Arsitektur Android

\section{Linux Kernel}

Merupakan lapisan dimana inti dari sistem operasi android itu berada. Berisi file-file sistem yang mengatur sistem processing, memory, resource, drivers, dan sistem-sistem operasi android lainnya.

\section{Libraries}

Pada libraries terdapat semua kode yang menyediakan fitur utama sistem operasi android. Sebagai contoh, libraries SQLite menyediakan dukungan database sehingga dapat menggunakannya untuk penyimpanan data. Libraries webkit menyedikan fungsionalitas untuk browsing web.

\section{Android Runtimes}

Pada lapisan yang sama seperti libraries, android runtime menyediakan satu set libraries inti yang memungkinkan pengembang untuk membuat aplikasi android menggunakan bahasa pemrograman Java. Android runtime juga termasuk mesin virtual Dalvik yang memungkinkan setiap aplikasi android untuk berjalan dalam prosesnya sendiri, Dalvik adalah sebuah mesin virtual yang dirancang khusus untuk android dan dioptimalkan untuk perangkat mobile bertenaga baterai dengan memori dan CPU yang terbatas.

\section{Application Framework}

Android menawarkan kepada pengembang atau memberi kemampuan kepada pengembang untuk membangun aplikasi yang bagus dan inovatif.

\section{Applications and Widget}

Lapisan ini merupakan tempat dimana pengguna berhubungan dengan aplikasi saja. Seperti mendownload dan menginstal aplikasi. Selain itu terdapat juga aplikasi intinseperti telepon, sms, kontak, browser, kalender, dan lain-lain. 


\subsection{Menghitung Jarak dengan Metode Haversine}

Untuk proses perhitungan jarak antara koordinat lokasi pengguna dengan koordinat lokasimerchant pada aplikasi ini diterapkan metode Haversine, karena seperti Haversine Formula biasa digunakan untuk menghitung jarak Orthodromic[3]. Jarak Orthodromic adalah jarak terpendek antara dua titik di permukaan bumi menggunakan garis lintang (longitude) dan garis bujur (lattitude) sebagai variabel inputan. Jarak Orthodromic bukan merupakan jarak garis lurus yang menghubungkan dua titik seperti pada jarak Euclidean. Jarak Orthodromic ikut memperhitungkan jari - jari kelengkungan bumi.

Haversine Formula untuk menghitung jarak Orthodromic dapat dinyatakan dengan persamaan 1.

$$
d=2 r \cdot \arcsin \left(\sqrt{\sin ^{2}\left(\frac{\emptyset_{2}-\emptyset_{1}}{2}\right)+\cos \left(\varnothing_{1}\right) \cdot \cos \left(\emptyset_{2}\right) \cdot \sin ^{2}\left(\frac{\gamma_{2}-\gamma_{1}}{2}\right)}\right) \ldots \ldots \ldots \ldots 1
$$

Keterangan:

$\mathrm{r}=$ Radius Bumi $=6371 \mathrm{~km}$

$\emptyset=$ Lattitude ( Bujur)

$\gamma=$ Longitude (Lintang)

$\mathrm{d}=$ Jarak

1 derajat $=0.0174532925$ radian

\subsection{Graf}

Graf digunakan untuk mempresentasikan obyek-obyek diskrit dan hubungan antara obyek-obyek tersebut. Graf adalah kumpulan simpul(nodes) yang dihubungkan satu sama lain melalui sisi atau busur (edges). Suatu graf G terdiri dari dua himpunan yaitu himpunan V berupa simpul atau vertex dan himpunan E berupa busur atau edge.

Simpul-simpul pada graf dapat merupakan obyek sembarang seperti kota, pulau, nama buah, dan sebagainya. Busur dapat menunjukkan hubungan seperti rute jalan, rute penerbangan, sambungan telepon, dan lain-lain. Notasi graf $G(V, E)$ mengandung arti bahwa graf $G$ memiliki V simpul dan E busur.

\section{METODE PENELITIAN}

\section{Analisa kebutuhan data}

Kebutuhan umum data untuk aplikasi yang berjalan adalah :

a. Data merchant/toko roti dan kue

Datamerchant meliputi nama merchant, alamat, koordinat lokasi, telepon, kategori merchant, serta username dan password dari merchant yang memiliki iklan untuk di promosikan. Data ini di dapat dari hasil survey lapangan, pencarian dari internet serta data dari dinas perindustrian mengenai daftar toko roti dan kue di Yogyakarta.

b. Data iklan/promosi

Data iklan berisi mengenai detail iklan yang dimiliki oleh masing-masing merchant. Data ini didapat dari survey lapangan serta pencarian informasi melalui internet.

c. Data Admin

Data admin meliputi username dan password dari admin yang dapat melakukan pengolahan data, admin terdiri dari admin aplikasi dan admin dari masing-masing merchant yang terdaftar.

d. Data Jalan

Data jalan yang dipakai adalah data jalan yang ada di kota Yogyakarta. Adapun jalan yang dipakai ialah jalan nasional, jalan provinsi serta jalan kota atau kabupaten.

\section{Analisa Proses}

Adapun proses atau langkah kerjanya yakni pertama admin aplikasi akan membuka dan login ke website pengelolaan dan menjalankan web servicenya, ketika awal sekali belum ada data maka admin akan menginputkan semua data yang dibutuhkan seperti yang ada dalam tabel 
di database, kecuali data promosi. Hal ini karena data promosi akan diinputkan oleh merchant yang bersangkutan. Kemudian ketika sudah ada data merchant yang terdaftar dan melakukan permintaan untuk approved promosi, maka admin akan mengecek kelayakan promo tersebut dan melakukan approved promo untuk dapat diterbitkan sebagai notif promo. Ketika pengguna smartphone mulai menjalankan aplikasi ini, maka aplikasi akan meminta lokasi koordinat user saat ini kepada sistem GPS. Kemudian GPS akan mendeteksi lokasi keberadaan user dan menampilkan koordinat user berada. Kemudian aplikasi akan mengirim data koordinat lokasi user ke server untuk dilakukan perhitungan jarak menggunakan metode Haversine guna meminta promo terdekat yang ada disekitar area user. Disini server data akan mengecek keaktifan iklan yang ada kemudian mengirimkannya kepada pengguna berdasarkan subscribeyang telah dipilih, atau umum. Dengan berlangganan maka pengguna akan lebih mudah dalam mendapatkan berbagai iklan penawaran menarik dari produk yang disukai. Tanpa perlu mencari-cari iklan lebih banyak lagi.

Setelah mendapat data promo dari merchant yang terdekat maka aplikasi akan menampilkannya ke dalam layar HP pengguna, untuk menggunakan promo tersebut pengguna bisa memilih salah satu iklan yang didapat kemudian akan diarahkan ke halaman detail promo sehingga pengguna bisa melihat promo dengan lebih jelas lagi. Pada halaman ini terdapat tombol "Show Map" untuk melihat rute menuju lokasi merchant melalui sebuah peta, dimana aplikasi akan mengirim koordinat lokasi tujuan ke server untuk selanjutnya server akan mengirimkan peta beserta rute terpendek sampai ke lokasi merchant berada. Terdapat juga tombol "Call Merchant" untuk menelpon merchant, aplikasi ini juga menyediakan tombol "Share Promo" untuk para pengguna yang ingin membagikan promo ke media sosial. Setelah melihat detail promo maka pengguna bisa sampai ke lokasi merchant yang akan di tuju.

\section{Pencarian jarak dengan metode haversine}

Adapun proses pencarian promosi dari merchant yang lokasinya paling dekat dengan pengguna dimulai dengan mendeteksi titik koordinat keberadaan pengguna saat ini, kemudian titik tersebut akan dibandingkan dengan koordinat-koordinat dari para merchant yang mempunyai promosi dengan menggunakan rumus jarak haversine. Dari keseluruhan data merchant yang diperoleh dari hasil perbandingan tersebut, maka akan diambil titik lokasi yang paling dekat dengan koordinat pengguna, untuk kemudian akan ditampilkan kepada pengguna. Adapun Gambar 2 akan menjelaskan proses penggunaan rumus haversine dalam bentuk flowchart.

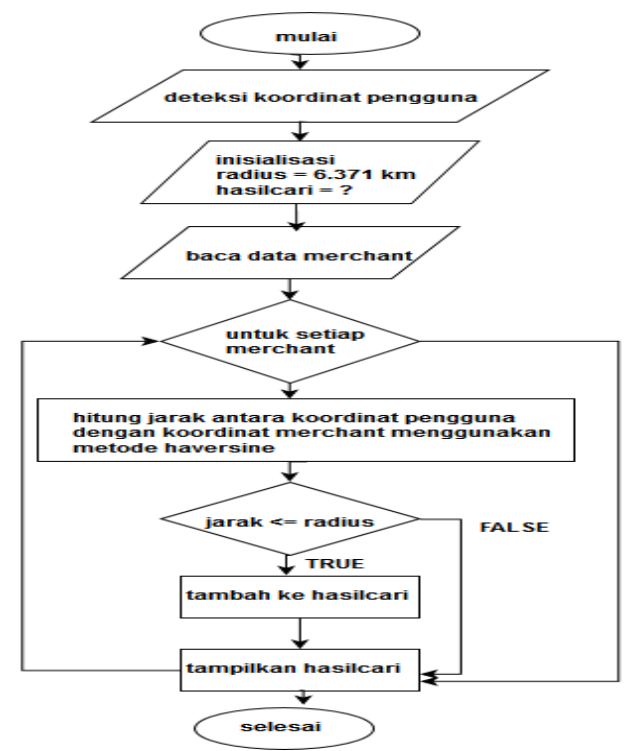

Gambar 2. Flowchart pencarian promosi dari merchant yang terdekat 


\section{HASIL DAN PEMBAHASAN}

Dari Gambar 3 ini dapat dilihat bahwa pembangunan sistem ini membutuhkan server yang nantinya terhubung dengan Android Devalopment Tools (ADT) menggunakan koneksi Internet.

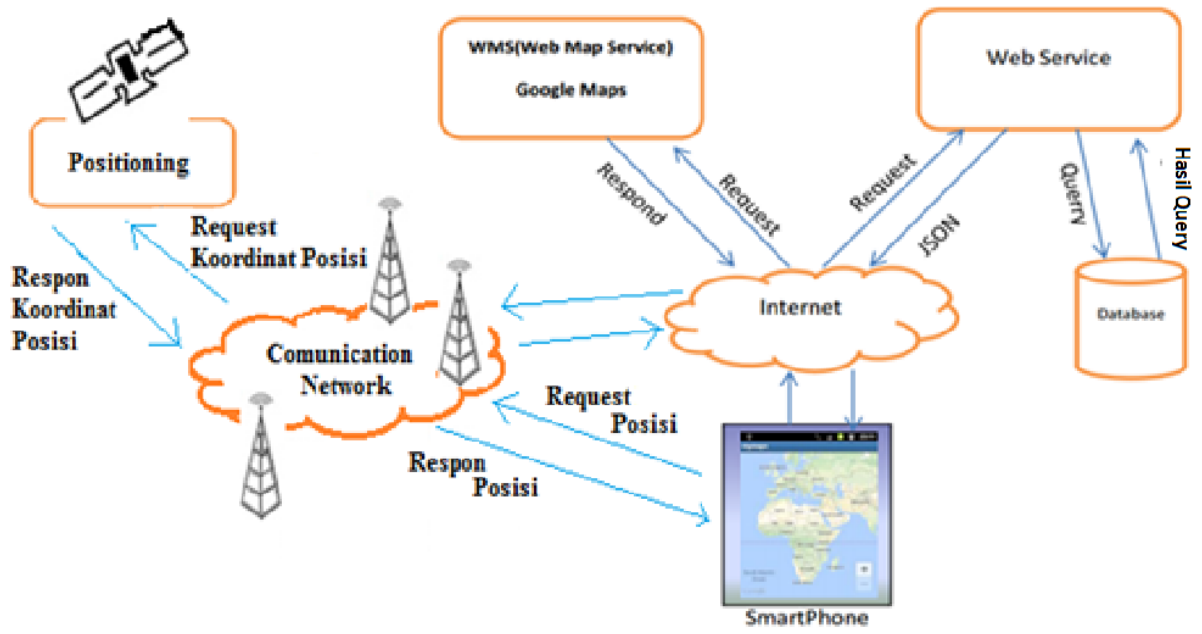

Gambar 3. Arsitektur Sistem LBS yang dibangun

Pada Gambar 3 ditunjukkan arsitektur sistem dari aplikasi dimana cara kerjanya adalah sebagai berikut :

a. Ketika fungsi pencarian telah diaktifkan, posisi pengguna sebenarnya berasal dari perangkat mobile diperoleh dari Positioning Service. Hal ini dapat dilakukan baik oleh perangkat menggunakan GPS sendiri atau layanan posisi jaringan yang berasal dari provider (Cell Tower). Setelah itu perangkat mobile pengguna mengirimkan permintaan informasi promosi yang lokasinya paling dekat dan mengirimkan posisi melalui jaringan komunikasi ke gateway telekomunikasi.

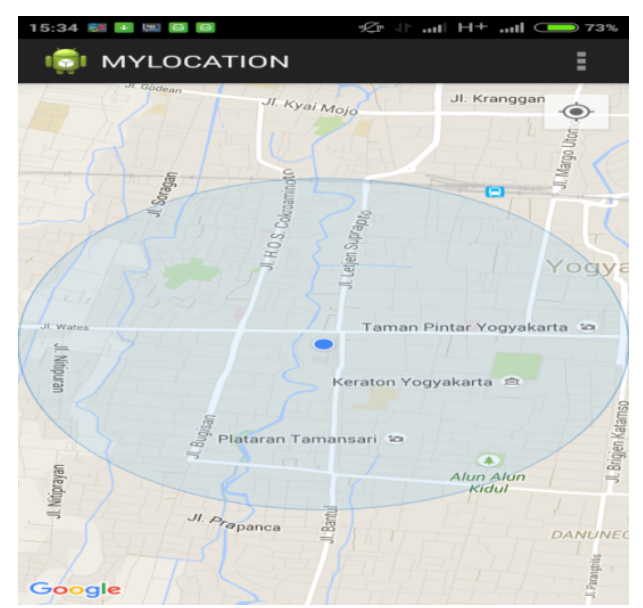

Gambar 4 Tampilan letak lokasi pengguna

Di dalam My Location terdapat fungsi SetMyLocation () untuk mengambil latitude dan longitude keberadaan user atau pengguna saat itu secara otomatis.

b. Gateway memiliki tugas untuk bertukar pesan di antara jaringan komunikasi selular dan internet. Oleh karena itu dia mengetahui alamat web dari beberapa aplikasi server dan rute permintaan ke spesifik server tertentu. Gateway akan menyimpan juga informasi tentang perangkat mobile yang telah meminta informasi

c. Aplikasi server membaca permintaan dan mengaktifkan layanan yang terkait. 

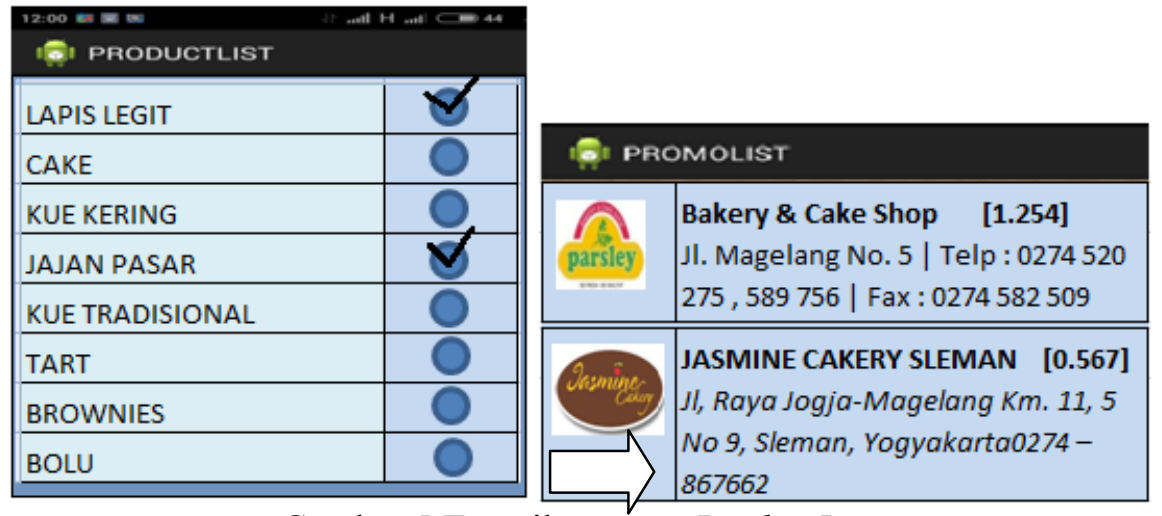

Gambar 5 Tampilan menu ProductList

Didalam ProductList terdapat 8 kategori produk yang ditawarkan dalam aplikasi adapun web service JSON akan mengambil data dari URL produk.php untuk dapat ditampilkan kedalam layar HP pengguna. Data yang diambil berupa nama kategori, serta checklistnya. Data hasil pengambilan dari URL yang akan ditampilkan kedalam datalist class product. Selanjutnya apabila ada list yang di klik, maka program akan memanggil class PromoList untuk startActivity atau memulai aktifitasnya menampilkan berbagai promo yang sedang berlangsung. Promo ini ditampilkan berdasarkan lokasinya yang terdekat dengan pengguna. Dimana apabila user mengklik salah satu dari daftar promo yang ditampilkan makan user akan dibawa ke tampilan selanjutnya yakni Gambar 6 bagian DetailPromo, guna melihat promo secara lebih rinci lagi.

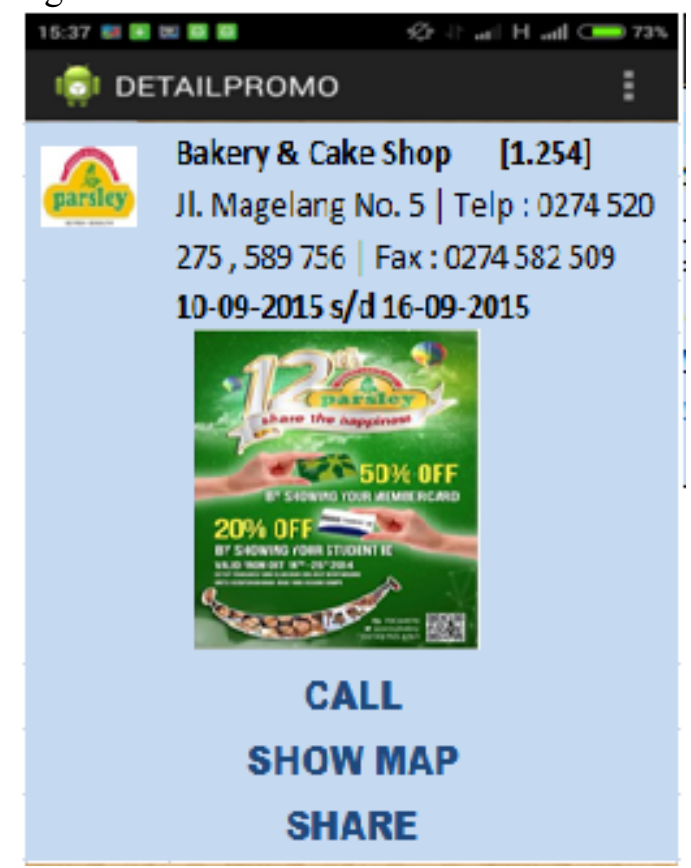

Gambar 6 Tampilan detail promo

d. Kemudian, service menganalisis lagi pesan dan memutuskan mana informasi tambahan selain criteria pencarian dan posisi pengguna diperlukan untuk menjawab permintaan pengguna. Dalam kasus ini service akan menemukan bahwa pengguna membutuhkan suatu informasi dari database yellow pages pada wilayah tertentu dan kemudian service tersebut akan meminta penyedia data untuk memberikan data tersebut

e. Selanjutnya service akan menemukan bahwa informasi tentang promo, jalan, jarak dan cara yang diperlukan untuk memeriksa apakah lokasi tujuan dapat dicapai

f. Setelah semua informasi service akan melakukan bufferspasial dan query routing untuk mendapatkan beberapalandmark terdekat. Setelah menghitung daftar landmark terdekat, hasil dikirim kembali ke pengguna melalui internet, gateway dan jaringan mobile. 
g. Kemudian, informasi akan disampaikan kepada pengguna baik dalam bentuk peta digital.

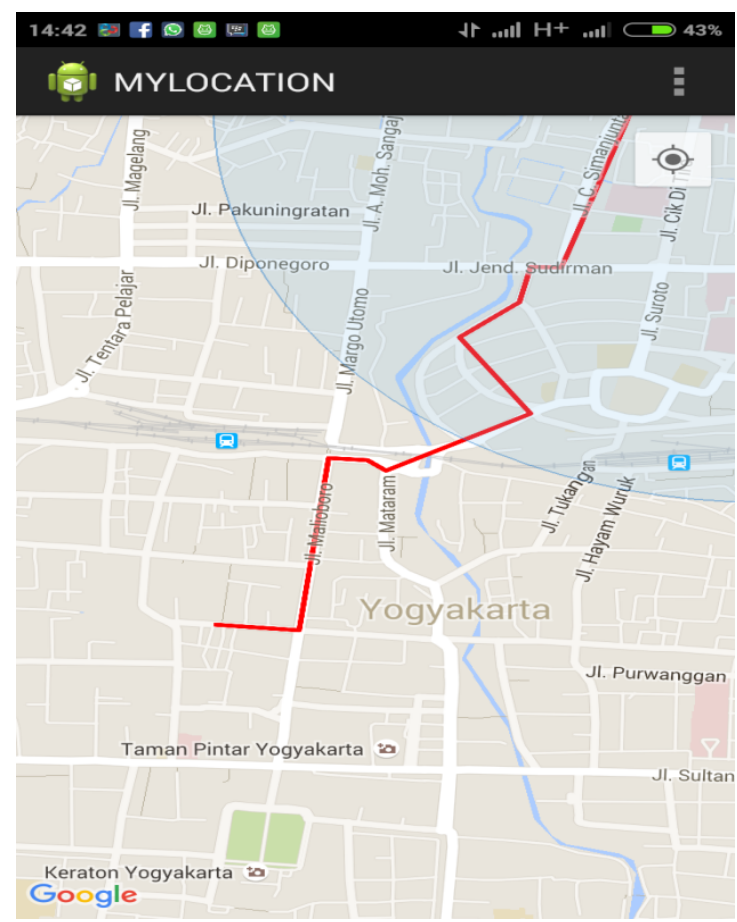

Gambar 7. Tampilan Map dan rute

Disini program akan memanggil service JSON untuk pemanggilan rute terpendek yang didapat. Dengan mengetahui lokasi asal dan tujuan maka rute dapat dengan mudah digenerate. Di dalam detail promo juga terdapat menu Share Promo seperti Gambar 8 dengan menu ini user dapat membagikan atau share promo-promo yang sedang berlangsung saat itu ke berbagai media social lainnya.
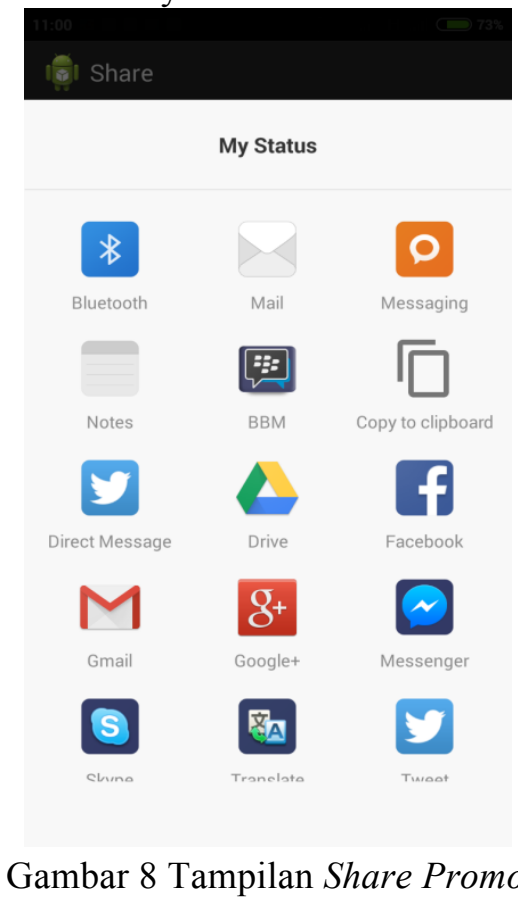

\section{KESIMPULAN}

Berdasarkan penelitian yang telah dilakukan serta hasil pengujian dari aplikasi LBS sebagai sarana promosi, maka dapat diambil kesimpulan sebagai berikut: 
a. Sudah dapat dibangun aplikasi yang dapat menampilkan iklan/promosi dari para merchant roti dan kue di wilayah Yogyakarta sesuai dengan produk yang telah dipilih oleh user.

b. Promo sudah berhasil dikirim melalui push notifikasi kepada user yang mencari promo.

c. Pencarian rute terpendek mampu menemukan tujuan dengan jarak yang relative singkat sekaligus menampilkannya pada peta google map.

\section{DAFTAR PUSTAKA}

[1] Kumar, S., Qadeer, M.A., and Gupta, A., 2009, Location Based Service using android, Departement of Computer EngineeringZakir Hussain College of Engineering and Technology, India.

[2] Virrantaus, K., Markkula, J., Garmash, A., and Terziyan, Y.V., 2001,Developing GISSupported Location-Based Services. In: Proc. of WGIS'2001 - First International Workshop on Web Geographical Information Systems., Kyoto, Japan. 423-432

[3] Adiwilaga, A., 2014, Teori Pengukuran Jarak, http://blogs.itb.ac.id/anugraha/ 2014/09/10/teori-pengukuran-jarak/ akses 2 September 2014 jam 13.45

[4] Brimicombe, A. and Li, C., 2009,Location Based Services and Geo-Information Engineering. Singapore: Faboulus Printers Pte Ltd.

[5] Rashid, O., Coulton, P., and Edward, R., 2008, Providing location based information/advertising for existing mobile phone users. Personal and Ubiquitous Computing. 12(1), 3-10.

[6] Sunyoto, A., 2009,Api Location (Jsr 179): Standar Penentuan Posisi Untuk Telepon Seluler Berkemampuan Java, Jurnal Dasi, Vol 10. No 1.

[7] Kotler, Philip and Keller. L.K., 2012.Marketing Management, 12th edition.United States of America: Pearson

[8] Jefkins, Frank., 1997, Periklanan., Jakarta: Erlangga

[9] T. D'Roza and G. Bilchev, 2003, An overview of location-based services. BT Technology Journal 21(1): 20-27,

[10] Wei, Meng Lee., 2011, "Beginning Android Application Development”, Wiley Publishing. Inc. Indianapolis. 